\title{
Corynebacterium nebraskense, a New, Orange-Pigmented Phytopathogenic Species ${ }^{1}$
}

\author{
ANNE K. VIDAVER and MANLEY MANDEL
}

\begin{abstract}
Department of Plant Pathology, University of Nebraska, Lincoln, Nebraska, 68503, and The University of
Texas System Cancer Center, M.D. Anderson Hospital and Tumor Institute, Houston, Texas 77025
\end{abstract}

\begin{abstract}
A new species of Corynebacterium isolated from field corn is described. The isolates form a homogeneous group that is recognized as a new species, Corynebacterium nebraskense. The organism is characterized by orange-pigmented colonies, inability to grow on $0.005 \%$ triphenyltetrazolium chloride agar, specific bacteriophage sensitivity, and a guanine plus cytosine content of $73.5 \mathrm{~mol} \%$. These and other characters differentiate this organism from other described phytopathogenic corynebacteria. The type strain of $C$. nebraskense is Fur-1 (= ATCC 27822 = NCPPB 2578).
\end{abstract}

A bacterial disease of field corn characterized by a distinctive foliar blight was first observed in south central Nebraska in 1969. In subsequent years, the disease, called Goss's bacterial wilt and blight (synonymous with leaf freckles and wilt), was found in other areas in Nebraska as well as in neighboring Iowa and Kansas (12). Preliminary investigation showed that a specific corynebacterium was associated with the disease. The bases for differentiating this bacterium from other phytopathogenic corynebacteria are presented in this paper. A preliminary report, including host range data, has been published (8).

\section{MATERIALS AND METHODS}

Bacterial isolates. Fifteen isolates were obtained from different field-corn hybrids collected throughout Nebraska over a 3-year period. Isolations were made principally from leaf material, but also from stalks, using a modification of a direct puncture method (2) in which a sterile dissecting needle was used to puncture margins of lesions and to streak directly onto agar plates. The orange-pigmented isolates derived from such material reproduced disease symptoms when inoculated into stems of 10-day-old seedlings of either sweet corn (Golden Cross Bantam) or field corn (Nebraska 501-D).

Methods. The methods used for characterization of the isolates were generally as described previously (9), except that for deoxyribonucleic acid extraction the cells were treated with lysozyme $(100 \mu \mathrm{g} / \mathrm{ml})$ in the presence of saline-ethylenediaminetetraacetate for $3 \mathrm{~h}$

\footnotetext{
${ }^{1}$ Research conducted under project no. 21-21. Published as paper no. 3841, Journal Series, Nebraska Agriculture Experiment Station.
}

at $37 \mathrm{C}$ prior to lysis with sodium dodecyl sulfate. All tests were repeated at least three times.

Growth on $0.005 \%$ triphenyltetrazolium chloride agar or $0.0005 \%$ iodonitrotetrazolium chloride agar was determined by using Kelman medium (5), except that glucose was added separately and the stock solutions of tetrazolium salts were filter-sterilized prior to use.

Bacteriophage sensitivity was determined by spot tests with four purified phage isolates. The phages were isolated from soil or plant debris as previously described (11), using three different isolates of the new corynebacterium for initial phage enrichment. (These bacteriophages, $\phi \mathrm{C} 8, \phi \mathrm{C} 11, \phi \mathrm{C} 12$, and $\phi \mathrm{C} 2 \mathrm{~A}$, will be described in a separate communication.) Phages titering $0.5 \times 10^{7}$ to $1.0 \times 10^{7}$ plaque-forming units per $\mathrm{ml}$ were spotted on lawns of bacteria with a Cooke Microdiluter (Cooke Engineering Co.).

\section{RESULTS}

Morphology. Cells of the new isolates were gram-positive, pleomorphic rods characteristic of coryneform bacteria. All isolates were nonmotile and without flagella (Fig. 1). Cells from 40-h-old cultures grown at $24 \mathrm{C}$ were 0.25 to 0.5 by 0.75 to $2.7 \mu \mathrm{m}$, with average dimensions of 0.5 by $2.0 \mu \mathrm{m}$, as determined by light and electron microscopy.

Cultural characteristics. Growth on nutrient broth-yeast extract agar (10), on potato-dextrose agar, and on a synthetic medium supplemented with yeast extract was slow, with visible colonies rarely appearing before 3 to 4 days. Yeast extract (Difco) was necessary for growth. Differentiation of colony characteristics was possible after about 5 days. Three colony types were observed on nutrient broth- 

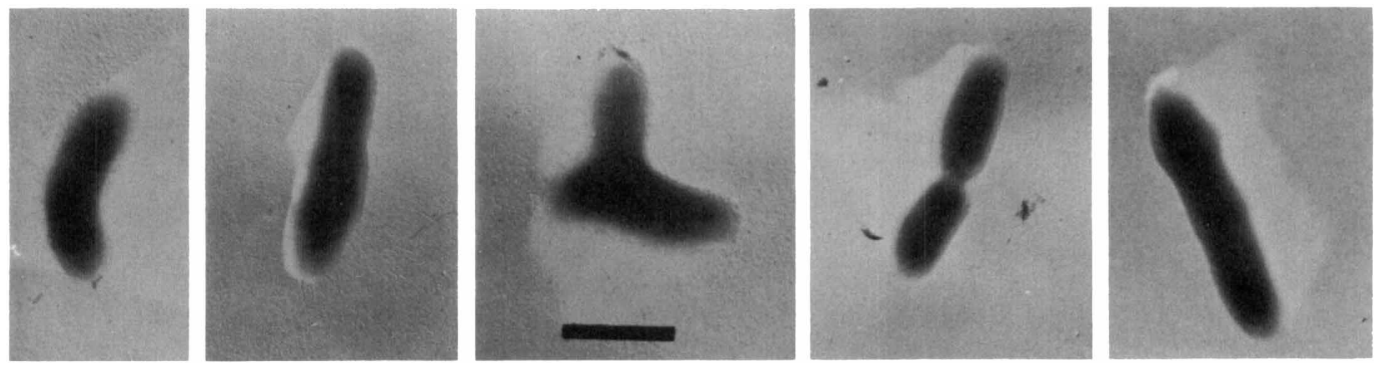

FIG. 1. Electron micrographs of Corynebacterium nebraskense sp.nov., isolate DC-1. The line marker indicates $1 \mu \mathrm{m}$.

yeast extract agar from primary isolations. All colony types were capucine or apricot-orange pigmented at room temperature $(22$ to $26 \mathrm{C})$. However, the intensity of pigmentation varied with the temperature and medium. The most frequent colony type was circular, convex, glistening, and butyrous with entire margins which were delimited from a central, darker zone. The second most frequent type was similar except that it lacked the outer margin. Both of these colony types averaged 3 to $5 \mathrm{~mm}$ in diameter after 5 to 7 days. The rarest colony type (isolated only once) was much smaller, reaching a maximal diameter of $1 \mathrm{~mm}$ in 5 to 7 days, and also lacked the outer margin.

Physiological and biochemical properties. Table 1 shows the characteristics of 15 isolates of the new bacterium in comparison with other species of phytopathogenic corynebacteria. The new bacterium can be differentiated from these other corynebacteria on the basis of fermentation reactions, pigmentation, motility, growth on TTC and INT agar, bacteriophage sensitivity, and mole percent guanine plus cytosine.

All isolates of the new pathogen were susceptible to one or more of the phages. At concentrations 10 to 100 times higher than those used in the routine tests reported here, one $C$. insidiosum strain was sensitive to all four phages.

The isolates were oxidase negative when tested as previously described (9).

Temperature relationships. All isolates grew on nutrient broth-yeast extract agar at $10 \mathrm{C}$ but not at $37 \mathrm{C}$. The optimal temperature for growth was between 24 and $28 \mathrm{C}$.

Type strain description. Pleomorphic, grampositive, nonmotile rods, approximately 0.5 by $2.0 \mu \mathrm{m}$, occurring singly or in pairs at generally obtuse angles. Orange-pigmented colonies on nutrient broth-yeast extract agar (10). Grows on $\mathbf{0 . 0 0 0 5 \%}$ iodonitrotetrazolium chloride agar but not on $0.005 \%$ triphenyltetrazolium chloride agar. The optimal growth temperature is approximately $26 \mathrm{C}$. The oxidase reaction is negative. Acid is produced from glucose, sucrose, mannose, xylose, and galactose in 7 days; no acid is produced from arabinose, raffinose, or trehalose. This strain is sensitive to bacteriophages $\phi \mathrm{C} 8, \phi \mathrm{C} 11, \phi \mathrm{C} 12$, and $\phi \mathrm{C} 2 \mathrm{~A}$. The deoxyribonucleic acid contains $73.5 \mathrm{~mol} \%$ guanine plus cytosine.

The type strain is Fur-1; it has been deposited in the American Type Culture Collection (ATCC), Rockville, Md., under the number 27822, and also in the National Collection of Plant Pathogenic Bacteria (NCPPB), Harpenden, England, under the number 2578.

\section{DISCUSSION}

The genus Corynebacterium is a heterogeneous group of microorganisms characterized by morphological pleomorphism. On the basis of guanine plus cvtosine content, it is clear that, with the possible exception of $C$. fasctans, the phytopathogenic species of Corynebacterium differ from other species of this genus $(3,4,6$, 13).

The plant pathogenic coryneform bacteria had been divided into two broad groups by Lelliott (6); recently, on the basis of new data, he has divided them (personal communication) into five groups for the forthcoming 8 th edition of Bergey's Manual. The original grouping (6) included the nonmotile, slow-growing species $C$. fascians, $C$. insidiosum, $C$. michiganense, and $C$. sepedonicum in nne group and the flagellated, moderate- to rapid-growing phytopathogenic corynebacteria in a second group. In the new grouping, $C$. fascians is in group 1 , the corynebacteria causing gumming of inflorescences in group 2,C. sepedonicum is in group 3 , $C$. insidiosum and $C$. michiganense are in group 4 , and the flagellated corynebacteria are in group 5. The differential characters used in this study are generally in accord with those 


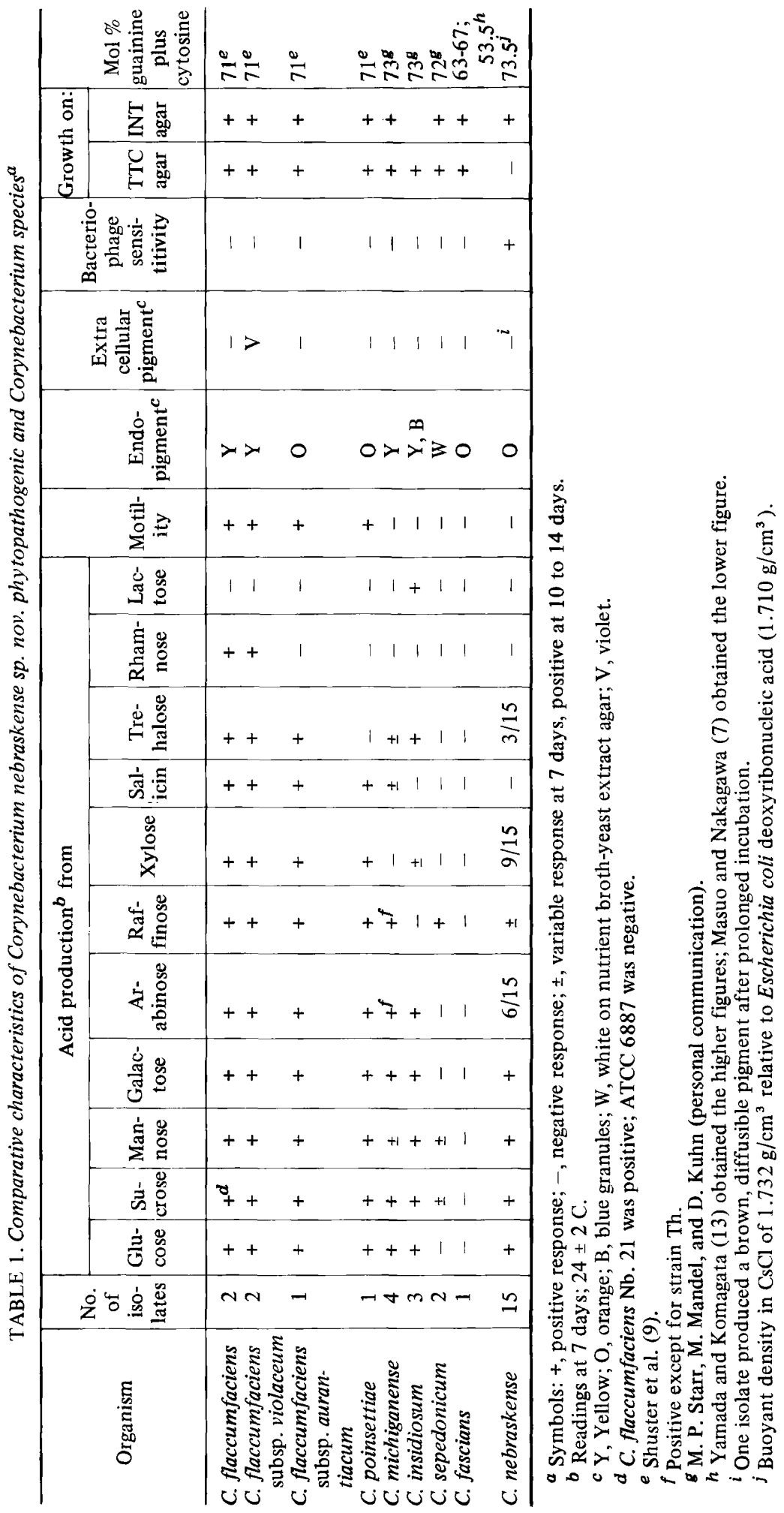


used by Lelliott for his revised grouping. Our data indicate that the new pathogen is closely related to $C$. michiganese and $C$. insidiosum. Such a relationship is also supported by preliminary serologic data (8).

The new bacterium is distinct from $C$. michiganense on the basis of differences in xylose and salicin utilization, pigmentation, inability to grow on triphenyltetrazolium chloride agar, and bacteriophage sensitivity. Lelliott (6) listed $C$. michiganense as not utilizing salicin, but all of our strains were positive. DaSilva and Holt (personal communication; reference 1) found that salicin utilization depended on the strain of $C$. michiganense tested. $C$. nebraskense can also be easily differentiated from $C$. insidiosum, the alfalfa wilt pathogen, on the basis of pigmentation, lactose and raffinose utilization, bacteriophage sensitivity, and growth on iodonitrotetrazolium chloride and triphenyltetrazolium chloride agars.

The differences between the new bacterium and previously described species warrant, in our opinion, the establishment of a separate species for the new bacterium for which the name Corynebacterium nebraskense is proposed (ne.bras.ken'se. M.L. adj. nebraskensis pertaining to Nebraska).

\section{ACKNOWLEDGMENTS}

This investigation was supported by the Agricultural Research Service Cooperative Agreement No. 12-14100-11198 (34).

We thank F. L. Lukezic, B. D. Thyr, G. A. Strobel, M. P. Starr, and C. I. Kado for some of the cultures used in this study, M. K. Brakke for the electron microscopy, and R. Carlson for excellent technical assistance.

\section{REPRINT REQUESTS}

Address reprint requests to: Dr. Anne K. Vidaver, The University of Nebraska-Lincoln, Department of Plant Pathology, Agricultural Experiment Station, Lincoln, Neb. 68503.

\section{LITERATURE CITED}

1. DaSilva, G. A. N., and J. G. Holt. 1965. Numerical taxonomy of certain coryneform bacteria. J. Bacteriol. 90:921-927.

2. Goth, R. W. 1965. Puncture method for isolating bacterial blights of bean. Phytopathology 55:930931.

3. Hill, L. R. 1966. A numerical taxonomy study of some corynebacteria and related organisms. J. Gen. Microbiol. 45:31-40.

4. Jones, L. A., and S. G. Bradley. 1964. Phenetic classification of Actinomycetes. Develop. Ind. Microbiol. 5:267-272.

5. Kelman, A. 1954. The relationship of pathogenicity in Pseudomonas solanacearum to colony appearance on a tetrazolium medium. Phytopathology 44:693-695.

6. Lelliott, R. A. 1966. The plant pathogenic coryneform bacteria. J. Appl. Bacteriol. 29:114118.

7. Masuo, E., and T. Nakagawa. 1969. Numerical classification of bacteria. III. Computer analysis of "coryneform bacteria." (3) Classification based on DNA base compositions. Agr. Biol. Chem. 33:1570-1576.

8. Schuster, M. L., B. Hoff, M. Mandel, and I. Lazar. 1973. Leaf freckles and wilt, a new corn disease, p. 176-191. Proc. 27th Annu. Corn and Sorghum Res. Congr., 14 to 15 December 1972, Chicago, Ill. In D. Wilkinson (ed.), American Seed Trade Association, Washington, D.C.

9. Schuster, M. L., A. K. Vidaver, and M. Mandel. 1968. A purple-pigment-producing bean wilt bacterium, Corynebacterium flaccumfaciens var. violaceum, n. var. Can. J. Microbiol. 14:423-427.

10. Vidaver, A. K. 1967. Synthetic and complex media for the rapid detection of fluorescence of phytopathogenic pseudomonads: effect of the carbon source. Appl. Microbiol. 15:1523-1524.

11. Vidaver, A. K., and M. L. Schuster. 1969. Characterization of Xanthomonas phaseoli bacteriophages. J. Virol. 4:300-308.

12. Wysong, D. S., A. K. Vidaver, H. Stevens, and D. Stenberg. 1973. Occurence and spread of an undescribed species of Corynebacterium pathogenic on corn in the western corn belt. Plant Dis. Reptr. 57:291-294.

13. Yamada, K., and K. Komagata. 1970. Taxonomic studies on coryneform bacteria. III. DNA base composition of coryneform bacteria. J. Gen. Appl. Microbiol. 16:215-224. 